Okatan, Ö. ve Özer, D. A. (2020). İlkokul birinci sınıf öğrencilerinin yazma becerilerinin betimlenmesi. Ana Dili Eğitimi Dergisi, 8(3), 720-731.

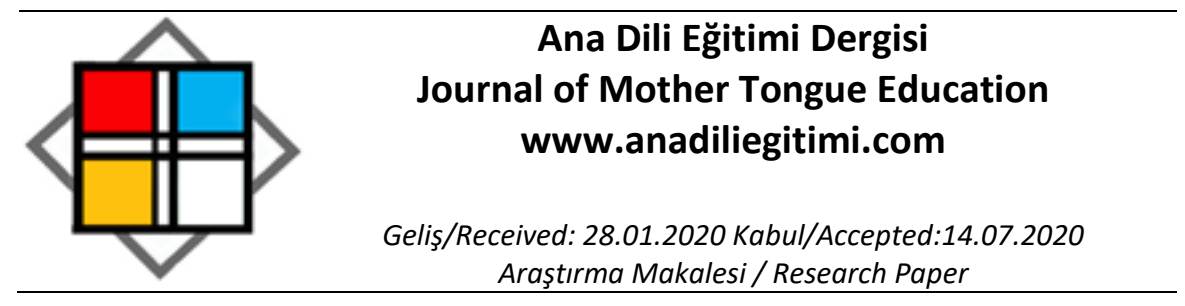

\title{
ilkokul Birinci Sınıf Öğrencilerinin Yazma Becerilerinin Betimlenmesi
}

\author{
Özlem OKATAN* \\ Derya ARSLAN ÖZER ${ }^{* *}$
}

\begin{abstract}
Öz
Bu araştırmada ilköğretim birinci sınıf öğrencilerinin dik temel yazı okunaklılığını ve hızını incelemek amacıyla betimsel tarama yöntemi kullanılmıştır. Çalışma 2019-2020 eğitim öğretim yılının birinci döneminde Burdur'da bir devlet okulunda eğitim gören 13'ü kız, 12'si erkek olmak üzere 25 birinci sınıf öğrencisine uygulanmıştır. Veri toplama aracı olarak "Dikte Çalışması Takip Formu" ve "ilkokullar İçin Hikâye Yazmaya Yönelik Bütüncül Puanlama Yönergesi” birinci sınıflara uyarlanarak kullanılmıştır. Öğrencilerin yazıları üç aralıklı boş satırlardan oluşan kâğıtlara alınmıştır. Öğrencilere dikte ve bakarak yazma çalışması için 3 dakika, serbest yazma için 20 dakika süre verilmiştir. Araştırmadan elde edilen bulgulara göre çalışmaya katılan birinci sınıf öğrencilerinin çoğunlukla eksik harf ve yanlış harf yazma hataları yaptıkları görülmüştür. Öğrenciler bakarak yazma çalışmasında dikte ve serbest yazmaya göre daha hızlı yazmaktadırlar. Öğrencilerin serbest yazmada metne uygun başlık koyabilme becerileri yeterli düzeydeyken olay örgüsü, yer, zaman, kişiler ve ana fikir belirtme becerileri yetersiz düzeydedir.
\end{abstract}

Anahtar Kelimeler: Yazı, okunaklılık, yazma hızı, birinci sınıf, dikte.

\section{Describing the Writing Skills of the First Grade Elementary School Students Abstract}

In this research, descriptive survey method was used to examine the legibility and speed of manuscript handwriting of the first-grade students. The study was applied to 25 first-grade students, 13 female and 12 male, from a public school in Turkey, Burdur province in the first semester of the 2019-2020 academic year. "Dictation Study Follow-Up Form" and "Holistic Rubric for Writing a Story for Elementary School" were adapted for first-grade students and used as data collection tools. Students were given 3 minutes for dictation and rewriting, and 20 minutes for free writing. According to the findings, it was observed that students mostly misspelled and missed a letter. Students wrote faster in rewriting sentences than dictation and free writing. While the ability of students to write appropriate titles in the free writing was sufficient, the storyline, place, time, people and main idea expression skills were observed as insufficient.

Keywords: Writing, legibility, writing speed, first-grade, dictation.

\section{Giriş}

Illetişim yöntemlerinden biri de yazmaktır. Yüz yüze iletişimin mümkün olmadığı durumlarda yazı bilgi akışını sağlamada başvurulan önemli bir araçtır. Dijital dünyanın gelişmesiyle de yazıı iletişim ve bilgiyi kayıt altına alma imkânı doğmuş, böylece yazı bilgi saklamada ve bilgiyi iletmede önemli bir araç haline gelmiştir. Akyol ve Yıldız'a (2018) göre tarih boyunca oynadığı rol dikkate alındığında yazı, insanlık tarihinin en önemli buluşu olma özelliğini korumaktadır. Kimine göre tarihin başlangıcı, kimine göre medeniyetin anahtarı, kimine göre de insanlığın belleğidir.

\footnotetext{
* Öğretmen, Atatürk illkokulu, Burdur, ogencer15@hotmail.com, ORCID: https://orcid.org/0000-0002-1862-719X

** Prof. Dr. Mehmet Akif Ersoy Üniversitesi, Eğitim Fakültesi, Sınıf Eğitimi Ana Bilim Dalı, Burdur, deryaarslan@mehmetakif.edu.tr, ORCID: https://orcid.org/0000-0002-4555-5435
} 
Yazmak, duygu ve düşünceleri sembollerle belli bir zemin (kâğıt gibi) üzerine kodlama sürecidir ve amaç anlatmak istediklerimizi kendimiz ya da başkaları için kayıt altına almaktır. Zamanla yazı yazmak öğrenmenin de bir aracı olmuştur. İlkokul birinci sınıfta öğrenilen yazı, okuma kadar olmasa da hayat boyunca devam eden bir eylemdir.

İlk okuma yazma öğretiminin genel amacı öğrencilerin; okula gelene kadarki yaşamış olduğu yaşantılarıyla kendiliğinden edindiği görsel okuma becerisi, dinleme becerisi, konuşma dili ve görsel sunu becerilerinden yola çıkılarak yaşam boyu kullanacağı nitelikli okuma yazma bilgi ve becerisini kazanabilmesidir. Ilk okuma yazma öğretimi sürecinde birinci sınıf öğretmeninin hedeflerinden biri, hızlı, akıcı, çağın gerekliliklerine uygun, eleştirel ve kurallarına uygun estetik, işlek ve okunaklı güzel yazma bilgi ve becerisi kazandırmak olmalıdır (Yılar, 2015). Yazı yazma öğretiminin temelinde çocukların hızlı ve okunakı bir yazı yazması yatmaktadır. Öğrencilerin yazılarında sıkça karşılaşılan sorunlardan biri de öğrencilerin yazısının okunaklı olmayışıdır (Coşkun, 2013). Okunaklılık harflerin eğimi, biçimi, aralarındaki boşluğu, boyutu ve satır çizgisine göre durumu ile ilgilidir ve yazma öğretiminin önemli bir unsurudur (Tok ve Erdoğan, 2017). Okunaklılık, yazılan yazının okuyucu tarafından doğru şekilde algılanmasıdır. Yazının güzel olması ile okunaklılık aynı şey değildir. Güzel yazı okunaklı olabilir fakat okunaklı yazı güzel yazı olmayabilir (Arslan Özer ve Bağcı, 2018).

İlkokul birinci sınıfta okuma yazma öğrenilirken yapılan yazı çalışmalarında öğrencilerden hem seviyelerine uygun yazılı ürünler ortaya koymaları hem de harfleri okunaklı ve doğru yazmaları beklenmektedir (Tok ve Erdoğan, 2017). Erdoğan'ın (2012) ilkokul birinci sınıf öğrencilerinin bitişik eğik yazı yazma süreçlerini incelemek amacıyla yaptığı çalışmada öğrencilerin yazılarının okunaklılık bakımından gelişim göstermediği ancak yazma hızı bakımından gelişim gösterdiği ortaya konulmuştur. Savaş (2017) el yazısı kullananlar ile dik temel yazı kullananların yazı okunaklılı̆ının orta düzeyde olduğunu belirtmektedir. Kuşdemir, Katrancı ve Arslan'a göre (2018) öğretmenlerin bir kısmı öğrencilerinin yazısını okunaklı kabul ederken, önemli bir kısmı da öğrencilerinin yazısını okunaklı olmadığını düşünmektedir. Bu araştırmada yer alan velilerin yarısından fazlası çocuğunun yazılarını okunaklı bulurken, bir kısmı da çocuğunun yazılarını okunaklılık açısından geliştirmesi gerektiği görüşünü belirtmiştir.

Yazının okunaklı olması kadar, uygun hızda yazılması da önemlidir. Bireyin yazma hızı yavaş olursa düşünce hızına yetişemez ve düşünülen bilgiden daha azı yazıya geçirilmiş olur. Ayrıca öğrencilerin öğrenim süresi boyunca yapılan birçok yazılı sınavda, var olan bilgisini ve düşüncesini sınırlı bir süre içinde, yazılı aktarması söz konusudur. Bu nedenle okuma yazmanın temelini oluşturan birinci sınıfta öğrencinin okuma yazmayı öğrendikten sonra, yazma becerisini belirli oranda hızlandırması beklenmektedir. Höbek ve Taşkaya'nın (2018) araştırmasında, ilkokul öğrencilerinin bitişik eğik yazı kullanırken yazma hızı bazı değişkenler bakımından araştırı ımışır. Elde edilen sonuçlara göre ilkokul öğrencilerinin yazma hızı; okul öncesine gidip gitmeme durumu, okulun bulunduğu bölge ve yazılan metnin türü açısından anlamlı farklııık göstermediği sonuçlarına ulaşılmıştır. Yazı hızı araştırmalarında hız, dakikada yazdığı doğru harf sayısına göre belirlenmektedir.

Yazma görevi için ayrılan süre, araştırmalarda farklılık göstermektedir. Yazı hızı ve okunaklılık çalışmalarında 1 dakika (Erdoğan, 2012), 1,5 dakika (Graham, Weintraub \& Berninger, 1998, Graham, Weintraub, Berninger \& Schafer, 1998, Graham, Weintraub \& Berninger, 2001), 2 dakika (Ziviani \& Elkins,1984, Ziviani \& Watson-Will, 1998), 5 dakika (Blöte \& Hamstra-Beltz, 1991; Hamstra-Bletz \& Blöte, 1993; Bara \& Morin, 2013; Roston, Hinojosa, \& Kaplan, 2008) gibi süreler belirlenerek, öğrencilerden bu süre içinde yazmaları beklenmektedir. Graham, Struck, Santoro, \& Berninger (2006), kompozisyon yazma için 5 dakika süre vermiştir.

Eğitim öğretimin temeli olan ilkokul yıllarında yazma becerilerini uygun düzeyde geliştiremeyen öğrenciler ileriki yıllarda yazma hızında düşüklük ve sınavlarda süreyi etkili kullanamama, bildiklerini yazılı aktaramama veya kendini yazılı ifade edememe gibi sorunlarla karşılaşabilmektedir. Ayrıca yazıda yaşanan problemler; yazı yazmayı sevmeme ve yazılı ürün ortaya koymaktan kaçınmaya neden olabilir. Illkokullarda 2005 yılından 2018 yılına kadar bitişik eğik yazı kullanılmıştır. 2018-2019 eğitim öğretim yılında Türkçe Programının değişmesiyle yazı stili tercihi sınıf öğretmenlerine bırakılmış, 2018-2019 eğitim öğretim yılında çoğunlukla dik temel harfler kullanılmaya başlanmıştır. On iki yıl boyunca ilk okuma yazma öğretiminde bitişik eğik yazı uygulaması olmasından 
dolayı, alan yazında bu araştırmanın da konusu olan ilkokullarda okunaklılık ve yazma hızı, bitişik eğik yazı yazmalar üzerinde ölçülmüştür (Coşkun, 2013; Erdoğan, 2012; Höbek ve Taşkaya, 2017; Höbek ve Taşkaya, 2018; Kuru, 2014; Kuşdemir vd., 2018). Yazı araştırmaları 2018 yılından bu yana dik temel yazı uygulamalarını incelemektedir. Alanda birinci sınıflar öğrencilerinin dik temel yazılarını inceleyen çalışmalar sınırlıdır (Gök ve Baş, 2020; Ulu, 2019).

Yazma becerilerini kazanmanın bu denli önemli olması ve yazma becerisinin temelinin ilkokul yıllarında atılıyor olması, dik temel yazı uygulamalarının yeniden uygulanmaya başlamasından dolayı bu araştırma, ilkokul birinci sınıf öğrencilerinin bakarak yazma, duyduğunu yazma (dikte) ve serbest yazma becerilerinin okunaklılık düzeyini ve yazma hızını ortaya koymayı amaçlamıştır. Okuma ve yazma becerileri birbirini destekleyen, çok önemli kazanımların ön şartı kabul edilen becerilerdendir. Alan yazına bakıldığında okuma üzerine çok fazla çalışmanın yer aldığı ancak yazma ile ilgili okumaya göre daha az çalışmanın bulunduğu görülmüştür. Ayrıca bu araştırmanın konusu olan birinci sınıflarda okunaklılık ve yazma hızı daha çok eğik el yazısı üzerinde çalışımıştır. Dik temel harflerle yapılmış benzer çalışmaların azlığı dikkat çekmektedir. Buradan hareketle araştırmanın amacı; ilkokul birinci sınıf öğrencilerinin dikte ve bakarak yazma çalışmalarındaki yazılarını okunaklılık ve hız açısından incelemek, serbest yazı çalışmalarını ise okunaklılık, hız ve içerik açısından incelemektir. Araştırmada bu amaca ulaşmak için aşağıdaki sorulara yanıt aranmıştır:

1. İlkokul birinci sınıf öğrencilerinin dinlediğini yazma (dikte), bakarak yazma ve serbest yazı okunaklılı̆ı nasıldır?

2. İlkokul birinci sınıf öğrencilerinin dinlediğini yazma (dikte), bakarak yazma ve serbest yazı hızı nedir? 3.llkkokul birinci sınıf öğrencilerinin serbest yazılarının içeriği ne düzeydedir?

\section{Araştırma Deseni}

\section{Yöntem}

Illkokul birinci sınıf öğrencilerinin yazılarının okunaklılık düzeyini ve yazma hızını belirlemeyi amaçlayan bu araştırmada "betimleyici tarama modeli" kullanılmıştır. "Sosyal bilimlerde sıklıkla kullanılan tarama araştırmaları, geniş gruplar üzerinde yürütülen, gruptaki bireylerin bir olgu ve olayla ilgili olarak görüşlerin, tutumlarının alındığı, olgu ve olayların betimlenmeye çalışıldığı araştırmalardır" (Karakaya, 2011, s.59). Tarama modeli, halen var olan bir olayın ya da geçmişte olmuş bir olayın araştırılarak betimlenmesi imkanını sunar. Bu modelde araştırmacı olayı etkileme, değiştirme amacı gütmez. Var olan durumu olduğu gibi betimlemeyi amaçlar.

\section{Çalışma Grubu}

Bu araştırmanın çalışma grubunu Burdur ilinin Gölhisar ilçesinde bir devlet okulunda okuyan 13'ü (\%52) kız, 12'si (\%48) erkek toplam 25 birinci sınıf öğrencisi oluşturmaktadır. Öğrencilerin 3'ü (\%12) solak, 22'si (\%88) sağlaktır. Öğrenciler farklı sosyo-ekonomik özelliklere sahiptir. Öğrencilerin tümü okul öncesi eğitimi almıştır. Öğrencilerin yaş aralığı birbirine yakındır (1 yıldan daha büyük fark içermemektedir). Çalışma grubunun belirlenmesinde kolay erişilebilir örneklem yöntemi tercih edilmiştir. Araştırma yapılan sınıfta, sınıf öğretmeninin ve öğrencilerin gönüllü katılımı dikkate alınmıştır. Araşsırma verileri 2019-2020 eğitim öğretim yılı birinci dönem sonunda (aralık ayında) yaklaşık bir hafta içinde toplanmıştır.

\section{Veri Toplama Araçları}

Bu araştırmada üç aralıkı kılavuz çizgili çalışma kâğıdı dikte, bakarak yazma ve serbest yazma çalışmalarında veri toplama aracı olarak kullanılmıştır. Bakarak yazma çalışmasında kullanılan 7 cümleden oluşan "Limonata" adlı metin, öğrencilerin düzeyine uygun olarak araştırmacı ve sınıf öğretmeni tarafından hazırlanmıştır. Ancak öğrencilere metnin uzun ve yorucu geleceği düşünülerek sınıf öğretmeni ile araştırmacının ortak kararı ile metnin yalnız ilk dört cümlesi çalışmada kullanılmıştır. Dikte çalışmasında ise öğrencilerin sınıf öğretmeninin belirlediği 4 cümlelik bir metni, belirtilen süre içinde duyarak yazmaları istenmiştir. Hem bakarak yazma metni hem de dikte çalışması metni belirlenirken, seçilen metinlerin o güne kadar öğrenilen tüm harfleri içermektedir. Serbest yazma konusu olarak "Ormandaki Hayvanlar" konusu belirlenmiştir. 
Dikte çalışması, bakarak yazma çalışması ve serbest yazma çalışmalarının okunaklılık değerlendirilmesi için "Dikte Çalışması Takip Formu" (Kuşdemir, Bulut, 2018) kullanılmıştır. Form hakkında ilgili uzman görüşü alınarak, 2 madde birinci sınıf öğrencilerinin seviyesinin üzerinde bulunduğu gerekçesiyle formdan çıkarılmıştır. Çıkarılan iki madde "Paragraf başı bırakma" ve "Yanlış yerde paragraf bırakma" dır. Ayrıca forma "Harfleri dik temel harf kurallarına uygun yazmama" maddesi eklenmiştir. Dikte Çalışma Takip Formuna toplam 10 maddelik son hali verilmiştir.

Serbest yazma için "illkokul 4. Sınıf Öğrencileri İçin Hikâye Yazmaya Yönelik Bütüncül Puanlama Yönergesi” (Kuşdemir, Bulut, 2018) birinci sınıflara uyarlanarak kullanılmıştır. Mevcut form üzerinden "Hikâye Taslağı Oluşturma" ve hikâyede giriş, gelişme, sonuç bölümlerinin değerlendirildiği "Anlatım Düzeni" başlıkları birinci sınıf seviyesinin üzerinde bulunduğu için araştırmacılar ve sınıf öğretmeninin ortak kararı ile formdan çıkarılmıştır. "ilkokullar İçin Hikâye Yazmaya Yönelik Bütüncül Puanlama Yönergesi" uzman görüşleri doğrultusunda son hali verilmiştir ve 6 maddeden oluşmaktadır.

Alanda yapılan yazı hızı ve okunaklılık çalışmalarında farklı süreler verilmiştir (Erdoğan, 2012; Graham, Weintraub \& Berninger, 1998, Graham, Weintraub, Berninger \& Schafer, 1998, Graham, Weintraub \& Berninger, 2001; Ziviani \& Elkins,1984, Ziviani \& Watson-Will, 1998; Blöte \& HamstraBeltz, 1991; Hamstra-Bletz \& Blöte, 1993; Bara \& Morin, 2013; Roston, Hinojosa, \& Kaplan, 2008; Graham, Struck, Santoro, \& Berninger, 2006). Bu çalışmada öğrencilere dikte ve bakarak yazma için 3 dk., serbest yazma için $20 \mathrm{dk}$. süre verilmiştir. Dikte ve bakarak yazma çalışmasında 3 , serbest yazma çalışmasında 20 dakika verilmesinin nedeni öğrencilerin birinci sınıf olması, yazı yazmayı yeni öğrenmeleri ve yazma deneyimlerinin sınırlı olmasıdır. Metinlerin seçilmesinde ve veri toplama araçlarının düzenlenmesinde ilk okuma yazma eğitimi alanında çalışan bir uzmanın ve iki sınıf öğretmeninin (mesleki kıdemi 20 ve 14 yıl) görüşleri alınmış ve görüşler doğrultusunda yukarıda belirtilen düzenlemeler yapılmıştır. Veri toplama araçlarının kullanımı ile ilgili geliştiren araştırmacılardan izin ileti yoluyla alınmıştır.

\section{Verilerin Toplanması}

Uygulama öncesinde uygulamanın yapılacağı birinci sınıfın sınıf öğretmeni ile, yapılacak çalışmanın günü görüşülüp uygulama saatleri belirlenmiştir. Yapılacak olan uygulamanın uygulanma şekli ve süre ile ilgili kıstaslar, sınıf öğretmenine araştırmacı tarafından açıklanmıştır. Öğrencilerin kendilerini rahat ve doğal bir ortamda hissetmesi açısından uygulamanın sınıf öğretmeni tarafından yapılmasına karar verilmiştir.

Bakarak yazma uygulaması ile ilgili öğrencilere açıklama yapıldıktan sonra, üstte metin altta üç aralıklı boş çizgilerden oluşan veri toplama aracı dağıtılmıştır. Öğrencilerin üstte yazan metni sayfanın aşağısında yer alan boş satırlara metne bakarak yazmaları istenmiştir. Üç dakika sonunda tüm kağıtlar toplanmıştır. Dikte çalışması için aynı öğrencilere başka bir ders saatinde üç aralıklı boş satırlardan oluşan veri toplama aracı dağıtılmış, öğretmenin söylediği cümleleri dinleyerek kâğıda yazmaları istenmiştir. Üç dakika sonunda tüm kağıtlar toplanmıştır. Serbest yazma uygulaması için aynı öğrencilere başka bir ders saatinde üç aralıklı boş satırlardan oluşan veri toplama aracı dağıtılmış ve "Ormandaki Hayvanlar" temalı bir yazıyı tasarlayarak verilen kâğıda yazmaları istenmiştir. Bu etkinlik için öğrencilere yirmi dakika süre verilmiştir. Süre sonunda dileyen öğrencilere iki dakika ek süre verilebileceği sınıf öğretmenine belirtilmiştir. Çalışmada öğrencilerden ek süre isteği gelmemiştir.

\section{Verilerin Analizi}

Verilerin analizine başlamadan önce öğrencilerden toplanan dikte, bakarak yazma ve serbest yazma ile ilgili çalışma kağıtları kendi içlerinde Ö1, Ö2 olarak kodlanmıştır. Dikte ve bakarak yazma çalışmalarında, öğrencinin yazma hızı belirlenirken 3 dakikada doğru yazılan harf sayısı 3'e bölünerek 1 dakikada doğru yazdığı harf sayısı hesaplanmıştır. Serbest yazma çalışmasında öğrencinin yazma hızını belirlemek için, 20 dakikada doğru yazdığı harf sayısı dikkate alınmıştır. Doğru yazılan harf sayısı 20'ye bölünerek 1 dakikada doğru yazdığı harf sayısı hesaplanmıştır. Serbest yazma çalışmalarında "ilkokullar İçin Hikâye Yazmaya Yönelik Bütüncül Puanlama Yönergesi" kullanılmıştır. Ölçekteki maddelere göre öğrencilerin serbest yazı çalışmaları 1-3 arası puan verilerek değerlendirilmiştir (1=Yetersiz; 2= Geliştirilmeli, 3= Yeterli). 
Bakarak yazma, dikte ve serbest yazma çalışmalarında öğrencilerin yazı okunaklıı̆̆ı, "Dikte Çalışması Takip Formu" ile değerlendirilmiştir. Formda yer alan ölçütler doğrultusunda öğrencilerin yazılarında hata tespiti yapılmıştır. Serbest yazma, bakarak yazma ve duyduğunu yazma (dikte) çalışmalarının okunaklılık açısından değerlendirilmesi ve serbest yazıların içerik analizi için dört ayrı puanlayıcının görüşüne başvurulmuş, güvenirlik analizi yapılmıştır. Puanlayıcılar; iki sınıf öğretmeni (mesleki kıdemi 20 ve 14 yıl), bir akademisyen ve araştırmacının kendisidir. Yıldırım ve Şimşek'e (2016) göre nitel çalışmalarda inandırıcılık ile ilgili alınan önlemlerden birisi de uzman görüşüdür. Bu araştırma araştırmanın desenini belirlemede, veri toplama araçlarını belirlemede, veri toplama süreçlerinde, verilerin analizinde ve çalışmanın raporlaştııılmasında ilk okuma yazma alanında uzman bir akademisyenin geri bildirimleri ile yürütülmüştür.

\section{Bulgular}

Araştırmadan elde edilen bulgular alt problemlere göre sınıflandırılmış olup aşağıdaki gibidir.

\section{îlkokul Birinci Sınıf Öğrencilerinin Dinlediğini Yazma (Dikte), Bakarak Yazma ve Serbest Yazma Yazı Okunaklılığı}

Illkokul birinci sınıf öğrencilerinin dinlediğini yazma (dikte), bakarak yazma ve serbest yazma yazı okunaklılı̆ı ile ilgili elde edilen bulgular Tablo 1'de verilmiştir.

Tablo 1.

Öğrenci Yazılarının Okunakııık Düzeyi

\begin{tabular}{lccc}
\hline Okunaklılık Maddeleri & Dikte & Bakarak Yazma & Serbest Yazma \\
\hline Büyük harfle yazması gerekirken küçük harfle yazma & 6 & 0 & 16 \\
Küçük harfle yazması gerekirken büyük harfle yazma & 1 & 0 & 13 \\
Birlikte yazılması gerekirken ayrı yazma & 0 & 0 & 9 \\
Ayrı yazılması gerekirken bitişik yazma & 0 & 2 & 17 \\
Eksik harf yazma & 8 & 4 & 21 \\
Fazla harf yazma & 3 & 0 & 11 \\
Yanlış harf yazma & 8 & 3 & 18 \\
Kelimeler arası gereğinden fazla boşluk bırakma & 0 & 0 & 4 \\
Fazladan kelime yazma & 0 & 1 & 7 \\
Harfleri dik temel harf kurallarına uygun yazmama & 6 & 6 & 15 \\
\hline \multicolumn{1}{c}{ Toplam } & 32 & 16 & 131 \\
\hline
\end{tabular}

Tablo 1 incelendiğinde birinci sınıf öğrencilerinin dikte, bakarak yazma ve serbest yazmada yaptıkları hatalar görülmektedir. Öğrencilerin bakarak yazma ( $f=16)$ ve dikte çalışmasında $(f=32)$ az hata yaptıkları görülmektedir. Serbest yazmayı yeni yeni öğrendikleri için hata sayısının fazla ( $f=131)$ olduğu görülmektedir. Çalışma sırasında yapılan hatalar büyük harfle yazması gerekirken küçük harfle yazma hatasını yapan dikte çalışmasında 6 öğrenci, serbest yazmada 16 öğrenci vardır. Bakarak yazmada ise bu hata hiçbir öğrencide gözlenmemiştir. Küçük harfle yazması gerekirken büyük harfle yazma hatasını yapan dikte çalışmasında 1 öğrenci, serbest yazmada 13 öğrenci vardır. Bakarak yazmada ise bu hata hiçbir öğrencide gözlenmemiştir. Birlikte yazııması gerekirken ayrı yazma hatasını yapan serbest yazmada 9 öğrencidir, dikte ve bakarak yazmada ise bu hatayı hiçbir öğrenci yapmamıştır. Ayrı yazılması gerekirken bitişik yazma hatasını yapan bakarak yazmada 2 , serbest yazmada 17 öğrenci olup, dikte çalışmasında ise bu hata hiçbir öğrencide gözlenmemiştir. Eksik harf yazma hatasını dikte çalışmasında 8 öğrenci, bakarak yazmada 4 ve serbest yazmada 21 öğrenci yapmıştır. Fazla harf yazma hatasını dikte çalışmasında 3 ve serbest yazmada 11 öğrenci yapmıştır. Bakarak yazmada ise bu hata hiçbir öğrencide gözlenmemiştir. Yanlış harf yazma hatasını dikte çalışmasında 8 öğrenci, bakarak 
yazmada 3 ve serbest yazmada 18 öğrenci yapmıştır. Kelimeler arası gereğinden fazla boşluk bırakma hatasını yapan serbest yazmada 4 öğrencidir. Dikte ve bakarak yazmada ise bu hata hiçbir öğrencide gözlemlenmemiştir. Fazladan kelime yazma hatasını bakarak yazmada 1, serbest yazmada 7 öğrenci yapmıştır, dikte çalışmasında ise bu hata hiçbir öğrencide gözlenmemiştir. Harfleri dik temel harf kurallarına uygun yazmayan dikte çalışmasında 6 öğrenci, bakarak yazmada 6 ve serbest yazmada 15 öğrenci vardır.

Araştırmaya katılan birinci sınıf öğrencilerine ait yazı örnekler Şekil 1, Şekil 2 ve Şekil 3’te verilmiştir.
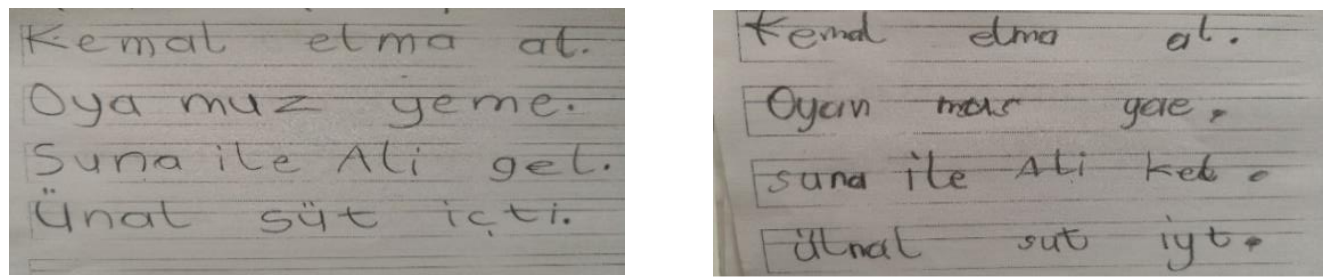

Şekil 1. Dikte çalışması yazı örnekleri (Ö11 ve Ö19’a ait)
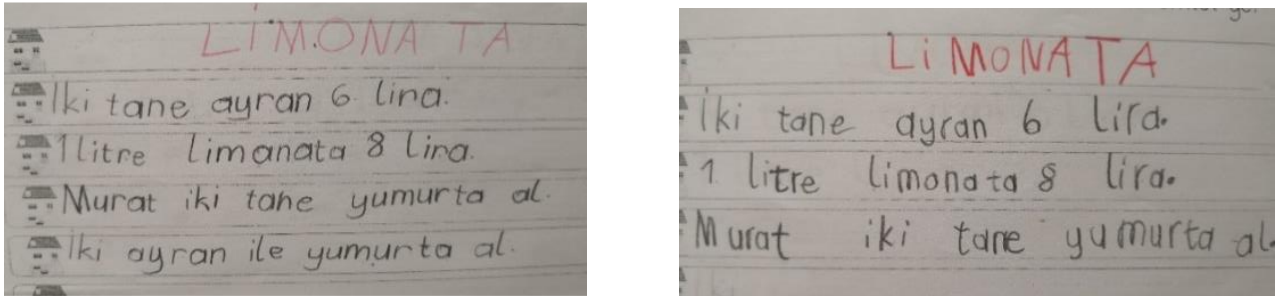

Şekil 2. Bakarak yazma çalışması yazı örnekleri (Ö18 ve Ö16’ya ait)
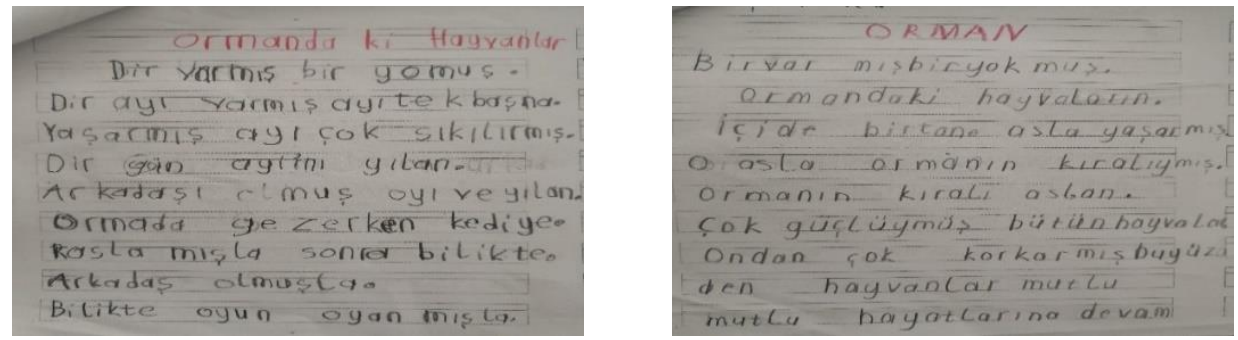

Şekil 3. Serbest yazma çalışması yazı örnekleri (Ö5 ve Ö2'ye ait)

Şekil 1, Şekil 2 ve Şekil 3'te verilen örneklerde de görüldüğü gibi öğrencilerin daha çok eksik harf yazma ve yanlış harf yazma gibi hataları göze çarpmaktadır. Bunun dışında göze çarpan bir hata da büyük harf kullanımı ile ilgilidir. Ayrıca her üç yazma çalışmasında da yazıların satır çizgisine denk getirmede sorun yaşandığı tespit edilmiştir. Bunun yanında harfler arasındaki boşluklar geniş bırakılmıştır.

\section{illkokul Birinci Sınıf Öğrencilerinin Dinlediğini Yazma (Dikte), Bakarak Yazma ve Serbest Yazma Hızı}

Yazma hızı belirlenirken duyduğunu yazma (dikte) ve bakarak yazmada öğrencilerin bir dakikada yazdığı doğru harf sayısı belirlenmiştir. Birinci sınıf öğrencilerinin dikte, bakarak yazma ve serbest yazma hızı ile ilgili bulgular Tablo 2'te verilmiştir.

Tablo 2.

Öğrencilerin Dikte, Bakarak Yazma ve Serbest Yazma Hızı

Öğrenci $\quad$ Dikte $\quad$ Bakarak yazma $\quad$ Serbest Yazma




\begin{tabular}{lccc}
\hline Ö1 & 15 & 14,3 & 6,9 \\
Ö2 & 15 & 14,6 & 16,4 \\
O33 & 15 & 17,3 & 7,5 \\
Ö4 & 15 & 8,6 & 1,5 \\
Ö5 & 15 & 16,3 & 5,5 \\
Ö6 & 29,3 & 19,3 \\
Ö7 & 15 & 21 & 17 \\
Ö8 & 15 & 20 & 9,2 \\
Ö9 & 15 & 21,7 & 12,7 \\
Ö10 & 8 & 22,7 & 8,1 \\
Ö11 & 14 & 21,7 & 17,5 \\
Ö12 & 12 & 16 & 7,9 \\
Ö13 & 13,3 & 8,5 \\
Ö14 & 13,3 & 24,7 & 6,5 \\
Ö15 & 12,3 & 11 & 6,1 \\
Ö16 & 6,3 & 21,7 & 4,1 \\
Ö17 & 7,3 & 14 & 1 \\
Ö18 & 15 & 8,3 & 2,6 \\
Ö19 & 14 & 28,3 & 9,4 \\
Ö20 & 14,6 & 8,3 & 10,4 \\
Ö21 & 15 & 18,3 & 6,4 \\
Ö22 & 15 & 20,7 & 6,2 \\
Ö23 & 15 & 26,3 & 6,3 \\
Ö24 & 15 & 13,7 & 14 \\
\hline
\end{tabular}

Tablo 2 incelendiğinde öğrencilerin büyük çoğunluğunun bakarak yazma hızı, dikte çalışmasındaki yazma hızından daha yüksektir (Ö3, Ö5, Ö6, Ö7, Ö8, Ö9, Ö10, Ö11, Ö12, Ö13, Ö14, Ö15, Ö16, Ö19, Ö21, Ö22, Ö23). Bazı öğrencilerin dikte çalışmasındaki yazma hızı, bakarak yazma çalışmasındaki yazma hızından daha yüksektir (Ö1, Ö2, Ö4, Ö18, Ö20, Ö24). Bir öğrencinin ise dikte çalışmasındaki yazma hızı, bakarak yazma çalışmasındaki yazma hızına eşittir (Ö17). Ö6 dikte, bakarak ve serbest yazma hızı en yüksek öğrencidir. Öğrencilerin genel olarak bakarak yazma hızları dikte yazma hızı ve serbest yazma hızından daha yüksektir. Dikte çalışmasında öğrencilerin dördü dışında (Ö9, Ö14, Ö15 ve Ö23) dikte çalışmasının sınıf tarafından birlikte yürütüldüğü söylenebilir.

\section{illkokul Birinci Sınıf Öğrencilerinin Serbest Yazma Düzeyleri}

İlkokul birinci sınıf öğrencilerinin serbest yazılı anlatım becerileri ile ilgili elde edilen bulgular Tablo 3'de verilmiştir.

Tablo 3.

Öğrencilerin Serbest Yazı Analizi Tablosu

\begin{tabular}{lccc}
\hline \multicolumn{1}{c}{$\begin{array}{c}\text { Yazı } \\
\text { unsurları }\end{array}$} & Yeterli (3) & $\begin{array}{c}\text { Öğrencilerin Yazı Düzeyleri } \\
\text { Geliştirilmeli (2) }\end{array}$ & Yetersiz (1) \\
\hline Başlık & 19 & 5 & 0 \\
Olay Örgüsü & 5 & 6 & 13 \\
Yer & 1 & 8 & 15 \\
Zaman & 0 & 7 & 17 \\
Kişiler & 0 & 15 & 9 \\
Ana fikir & 0 & 4 & 20 \\
\hline
\end{tabular}

Tablo 3 incelendiğinde tüm öğrencilerin hikâye başlığı kullandığı görülmektedir. Hikâye başlığını hikâye içeriğine uygun yazan 19 öğrenci, içerikle uyumsuz başlık yazan 5 öğrenci bulunmaktadır. Olay örgüsü bakımından incelendiğinde hikâye bir ya da iki olay çerçevesinde ilerleten 
ve öncelik-sonralık, sebep-sonuç ilişkisi kurabilen 5 öğrenci, hikâyede bir olaydan kısaca bahseden 6 öğrenci, herhangi bir olay örgüsüne yer vermeyen 13 öğrencidir. Hikâyede olayın geçtiği yeri detaylarıyla veren 1 öğrenci, sadece olay yerini belirten 8 öğrenci ve hiçbir yer belirtmeyen 15 öğrenci bulunmaktadır. Hikâyede zaman belirten 7 öğrenci, zaman belirtmeyen 17 öğrenci bulunmaktadır. Olayın zamanını oldukça açık ve detaylarıyla veren öğrenci görülmemektedir. Hikâyede olayı yaşayan esas kişi ve yardımcılar sadece isimleri ile veren 15 öğrenci, kişi bilgisi vermeyen 9 öğrencidir. Olayı yaşayan esas kişi ve yardımcıları tasvirleri ile veren öğrenci bulunmamaktadır. Hikâyede bir ana fikir işleyen 4 öğrenci, herhangi bir ana fikir işlemeyen 20 öğrencidir. Bir ana fikri hikâyenin geneline yayarak işleyen öğrenci bulunmamaktadır. Tablo 3 incelendiğinde özetle; çalışmaya katılan ilkokul birinci sınıf öğrencilerinin serbest yazma düzeylerinin "hikâyeye uygun başlık koyabilme" ölçütü dışındaki ölçütlerin geliştirilmeli ve yetersiz düzeyde olduğu görülmektedir.

\section{Tartışma ve Sonuç}

Ilkokul birinci sınıf yazı gelişiminde önemli bir sınıftır. Yazının temeli atılır ve bireyin yazı ile iletişiminin olumlu ya da olumsuz başlangıcı yapılır. Bütün eğitimlerin amacı bireylerde olumlu etkiler bırakmaktır. Bunu başarmak, sürece bırakarak, kendiliğinden olmasını bekleyerek değil, yazı eğitiminin birinci sınıftan başlayarak iyi analiz edilmesi ile olabilir. Yazı öğretiminde etkili bir yol haritasına intiyaç duyulmaktadır.

Araştırmanın amacı, bireyin yaşamı boyunca etkin olarak kullanacağı temel becerilerden biri olan yazı okunaklılığını, yazma hızını ve serbest yazı düzeyini ilkokul birinci sınıflarda belirlemektir. Arslan Özer ve Bağcı (2018)'ya göre yazıda okunaklılık önemli bir etkendir, yazının anlatmak istediği duygu ve düşüncelerin net olarak okuyucuya aktarılmasını sağlamaktadır. Okunaklılık, anlamdır. Bu nedenle yazıdaki anlamın okuyucuya aktarılması, okunaklı bir yazı ile mümkündür. Bu araştırma sonuçlarına göre ilkokul birinci sınıf öğrencilerinin bakarak yazma yazı okunaklılı̆ı, bakarak ve serbest yazmanın okunaklığından yüksektir. Dikte çalışmasındaki yazı okunaklılığı ise serbest yazma çalışmasındaki yazı okunaklığından daha yüksektir. Buradan hareketle okuma ve yazmayı henüz yeni öğrenmiş olan birinci sınıf öğrencileri, bakarak yazmada yazıyı aynen kopyalama konusunda başarıııdır. Ancak dikte çalışmasında sadece duymakla yetindikleri için yazıya aktarırken öğrendiği yazma bilgilerini de devreye sokması gerekmektedir. Ayrıca öğretmenin söyleyeceği yeni cümleye yetişebilmek için yazdığı cümleye odaklanamadıkları ya da öğrencilerin yolun başında olması sebebiyle zaman ile gelişebilecekleri söylenebilir. Okunaklıık puanları serbest yazma çalışmasında ise oldukça düşüktür. Serbest yazma çalışmasında öğrencinin tamamen kendi hayal ürünü olan hikâyeyi tasarlayıp cümleye dökmesi gerekmektedir. Burada birçok zihinsel süreç devreye girmektedir. Öğrenciden hem olayı kurgulaması hem yazım kurallarına uygun okunaklı yazması, hem de süreyi etkin kullanması beklenmektedir. Öğrencilerin çok azı bu süreci yönetebilmiştir. Henüz 3 ay önce okula başlamış olan ve harf öğrenme sürecini yeni tamamlayan birinci sınıf öğrencileri için bu sonuç şaşırtıcı değildir. Ayrıca sınıf öğretmeni sınıfta sık sık dikte ve bakarak yazma çalışması yaptığı, ancak ilk kez serbest yazma çalışması yaptığını belirtmiştir.

$\mathrm{Bu}$ araştırma sonuçlarına göre, serbest yazma çalışmasında 4 öğrenci kelimeler arası uygun boşluk bırakmamıştır. Coşkun (2013) ilkokul birinci sınıf öğrencilerinin ürettiği yazılarını Türkçe ve Bulgarca okuma yazma öğretim sürecinde okunaklııık açısından araştırdığı bir çalışmada Türkiye'de 3 Bulgaristan'da 3 öğrencinin yazılarında kelimeler arasında yeterince boşluk bırakılmadığını belirlemiştir. Ayrıca Bulgaristan'daki 5 öğrencinin ve Türkiye'deki 7 öğrencinin kelimeler arası boşluk bırakma konusunda desteğe ihtiyacı olduğu sonucu bulunmuştur. Türkiye'deki 15 öğrencinin 5'i ve Bulgaristan'daki 15 öğrencinin 7'si yazı yazarken kelimeler arası uygun boşluk bırakmıştır. Genel olarak araştırmaya katılan 30 öğrencinin 12'sinin, yazdıkları yazılarda kelimeler arası yeterince boşluk bırakma becerisine sahip olduğu görülmüştür.

Öğrenciler yanlış harf kullanma, eksik harf kullanma ve fazla harf kullanma gibi yazma hataları yapmıştır. A. F. Özcan ve A. Özcan'ın (2016) çalışmalarında; öğretmenler, birinci sınıf öğrencilerinin ilk okuma yazma öğrenirken sesleri ve yazılışları benzeyen harfleri hem dikte çalışmasında hem de okuma sırasında karıştırdıklarını belirtmiştir. 
Birinci sınıf öğrencilerinin yazı okunaklılığının belirlendiği bu çalışmada yazma hataları tespit edilmiştir. Okumayı yeni öğrenen bu öğrencilerin okuma yaptıkça yazma hatalarının da azalacağı düşünülmektedir. Tağa ve Ünlü’nün (2013) araştırmasında öğretmen görüşlerine göre yazma eğitiminde karşılaşılan öğrenci kaynaklı sorunlarda, öğrencilerin yeterince okuma alışkanlığının olmayışı öne çıkmaktadır.

Bu araştırmada öğrencilerin dikte, bakarak yazma ve serbest yazma sürecinde yazma hızları belirlenmiştir. Öğrencilerin genel olarak bakarak yazma çalışmasında diğer çalışmalardan daha hızlı yazdığı, dikte yazmada ise serbest yazma etkinliğinden daha hızlı yazdığı sonucuna ulaşılmıştır. Höbek ve Taşkaya (2017) öğretmenlerin öğrencilerinin yazma hızını önemsediklerini belirtmektedir. Öğrencilerin en azından orta düzeyde bir hıza sahip olmasının önemli ve gerekli olduğunu ve bunun için öğretmenlerin yazma hızını artırmaya yönelik daha fazla etkinlik yapması gerektiğini vurgulamışlardır. Demiroğlu Memiş'in (2018) ilkokul öğrencileri ile yaptığı bir çalışmada okunabilirlik arttıkça, yazma eğilimi puanlar da artmaktadır. Yazma eğilimi açısından tüm okunabilirlik boyutlarında, öğrenciler arasında anlamlı fark tespit edilmiştir. Ayrıca araştırmada yazı stili ile yazma hızı arasında orta seviyede pozitif anlamlı ilişki bulunmuştur.

Çalışmaya katılan ilkokul birinci sınıf öğrencilerinin serbest yazma çalışmasında içeriğe uygun başlık yazabilme becerisi yeterli düzeydedir. Ancak öğrencilerin serbest yazıları olay örgüsü, yer, zaman, ana fikir açısından yetersiz, kişiler açısından geliştirilebilir düzeydedir. Birinci sınıf öğrencilerinin yazı çalışmalarının başında olduğu düşünüldüğünde, yazı becerilerinin doğru şekilde kazanılması için yazma etkinliklerine daha fazla zaman ayrılabilir. Graham ve Rijlaarsdam'a (2016) göre çocuklar yazı yazmayı öğrenmek için mücadele eder ancak zorlanır. Şahin'in (2018) de belirttiği gibi öğrencilerin gelişim özellikleri dikkate alınmalıdır. Bunun sonucunda öğrencilerin sınıf düzeylerine göre ayrıntılı yazı geliştirme programları hazırlanabilir.

Yapılan çalışma sonucunda öğretmenler, öğrencilerin yazıları ile ilgili yazı öğretiminde okunaklılık çalışmalarına ve serbest yazma etkinliklerine ağırlık verebilir. Ayrıca yazma hızının farklı metin türlerine göre farklılaşıp farklılaşmadığı araştırılabilir. Aynı çalışma grubunun ileriki dönemlerde yazı okunaklılı̆ındaki değişimi ve yazma hızını inceleyen yeni araştırmalar yapılabilir.

\section{Kaynaklar}

Akyol, H. ve Yıldız, M. (2018). Kuramdan uygulamaya yazma öğretimi. Ankara: Pegem Akademi.

Arslan Özer, D. ve Bağcı, H. (2018). İlköğretim öğrencilerinin (2-7. Sınıf) yazı okunaklıı̆̆ı. Uluslararası Türk Eğitim Bilimleri Dergisi,6 (11), 2148-2314.

Bara, F. \& Morin, M.F. (2013). Does the handwriting style learned in first grade determine the style used in the fourth and fifth grades and influence handwriting speed and quality? A comparison between French and Quebec children. Psychology in the Schools, 50 (6), 601-617.

Bayraktar, V. ve Temel, F. (2014). Okuma-yazmaya hazırlık eğitim programının çocukların okumayazma becerilerine etkisi. Hacettepe Üniversitesi Eğitim Fakültesi Dergisi, 29 (3), 08-22.

Belet, D. ve Yaşar, Ş. (2007). Öğrenme stratejilerinin okuduğunu anlama ve yazma becerileri ile Türkçe dersine ilişkin tutumlara etkisi. Eğitimde Kuram ve Uygulama, 3 (1), 69-86.

Blöte, W. A., Hamstra-Bletz, L. (1991). A longitudinal study on structure of handwriting. Perceptual Motor Skills, 72, 983-994.

Coşkun, i. (2013). Türkiye ve Bulgaristan'da ilk okuma yazma sürecinde öğrencilerin ürettikleri yazıların okunaklılık bakımından incelenmesi. International Periodical For The Languages, 8 (8), 357-378.

Coşkun, Y. (2013). Türkçe ders kitaplarının PISA sınavı okuma ölçütleri açısından incelenmesi. Mehmet Akif Ersoy Üniversitesi Eğitim Fakültesi Dergisi, 26, 22-43.

Demiroğlu Memiş, A. (2018). Examination of legibility and writing speeds of primary school students with respect to writing disposition and writing style. Universal Journal of Educational Research, 6, (5), 1050-1059.

Erden, G., Kurdoğlu, F. ve Uslu, R. (2002). İlköğretim okullarına devam eden Türk çocuklarının sınıf düzeylerine göre okuma hızı ve yazım hataları normlarının geliştirilmesi. Türk Psikiyatri Dergisi, 13 (1), 5-13. 
Erdoğan, T. (2012). İlköğretim birinci sınıf öğrencilerinin bitişik eğik yazı yazma gelişimlerinin incelenmesi. Eğitim ve Bilim, 37 (165), 93-103.

Graham, S. ve Rijlaarsdam, G. (2016). Writing education around the globe:introduction and call for a new global analysis. Reading and Writing, 29, 781-792.

Graham, S., Struck, M., Santoro, J., \& Berninger, V. W. (2006). Dimensions of good and poor handwriting legibilityin first and second graders: Motor programs, visual-spatial arrangement, and letter formation parameter setting. Developmental Neuropsychology, 29 (1), 43-60.

Graham, S., Weintraub, N. \& Berninger, V. (2001). Which manuscript letters do primary grade children write legibly? Journal of Educational Psychology, 93 (3), 488-497.

Graham, S., Weintraub, N. \& Berninger, V.W. (1998). The relationship between handwriting style and speed and legibility. Journal of Educational Education, 91 (5).

Graham, S., Weintraub, N., Berninger, V.W. \& Schafer, W. (1998). Development of handwriting speed and legibility in grades 1-9. Journal of Educational Research, 92 (1), 42-51.

Gök, B. ve Baş, Ö. (2020). İlkokul 1. sınıf öğrencilerinin dik temel yazılarının okunaklılı̆ı üzerine bir inceleme. Ana Dili Ĕgitimi Dergisi, 8(2), 572-585.

Hamstra-Bletz, L., Blöte, W. A. (1993). A Longitudinal study on dysgraphic handwriting in primary School. Journal of Learning Disabilities, 26 (10), 689- 699.

Höbek, G. ve Taşkaya, S. M. (2017). Sını Öğretmenlerinin İlkokul Öğrencilerinin Yazma Hızına iliş̧kin Görüşleri. Çukurova Araştırmaları Dergisi, 3 (2), 117-125.

Höbek, G. ve Taşkaya, S., M. (2018). illkokul öğrencilerinin yazma hızının belirlenmesi. Hitit Üniversitesi Sosyal Bilimler Enstitüsü Dergisi, 11(3), 2433-2445. doi: 10.17218/hititsosbil.356223.

Karakaya, I. (2011). Bilimsel araştırma yöntemleri. Abdurrahman Tanrı̈ğen, (ed.). (2. Baskı). Ankara: Anı Yayıncılık.

Kuru, O. (2014). Sınıf Öğretmenliği 3. sınıf öğrencilerinin bitişik eğik yazılarının okunaklııık düzeylerinin belirlenmesi ve bitişik eğik yazıya ilişkin düşünceleri. Erzincan Üniversitesi Eğitim Fakültesi Dergisi, $16(1)$.

Kuşdemir, Y., \& Bulut, P. (2018). Yazmada ölçme ve değerlendirme. Edt. H. Akyol, M. Yıldız Kuramdan Uygulamaya Yazma Öğretimi içinde (s.285-320), Ankara: Pegem Akademi.

Kuşdemir, Y., Katrancı, M. ve Arslan, F. (2018). Veli ve Öğretmen Gözüyle İlkokul Öğrencilerinde Yazı Okunaklılığı. Ana Dili Eğitimi Dergisi, 6 (2), 455-476.

Özcan, A. F. ve Özcan, A. O. (2016). İlk okuma yazma öğrenmede çocukların yaşadıkları güçlükler, nedenleri ve çözüm önerileri: nitel bir araştırma. iGÜSBD, 3 (1), DOI: http://dx.doi.org/10.17336/igusbd.61470.

Roston, K. L., Hinojosa, J., \& Kaplan, H. (2008). Using Minesota Handwriting assessment and handwriting checklist in screening first and second graders' handwriting legibility. Journal of Occupational Therapy, Schools \& Early Intervention, 1 (2), 100-115.

Şahin, A. (2018). Türkiye'deki bitişik eğik yazı uygulamalarının bilimsel araştırma sonuçlarına göre değerlendirilmesi. Turkish Studies, 13(4), 1083-1096.

Savaş, B. (2017). Yazma öğretiminin ilkokul öğrencilerinin okuma-anlama becerileri üzerine etkilerinin incelenmesi: dilbilimsel bir yaklaşım. Uluslararası Eğitim Bilimleri Dergisi, 4 (13), 120-140.

Tağa, T. ve Ünlü, S. (2013). Yazma eğitiminde karşılaşılan sorunlar üzerine bir inceleme. International Periodical For The Languages, 8 (8), 1285-1299.

Tok, R. ve Erdoğan, Ö. (2017). İlkokul 2. 3. ve 4. sınıf öğrencilerinin yazma becerilerinin İncelenmesi. YYÜ Eğitim Fakültesi Dergisi (YYU Journal Of EducationFaculty), 14 (1), 1003-1024.

Ulu, H. (2019). illkokul birinci sınıf öğrencilerinin dik temel yazılarının okunaklılık ve yazım hataları açısından incelenmesi. IJOFE, 5 (2), 195-211.

Yılar, Ö. (2015). Ilk okuma ve yazma öğretimi. Ankara: Pegem Akademi.

Ziviani, J. \& Elkins, J. (1984). An evaulation of handwriting performance. Educational Review, 36(3), 49-261.

Ziviani, J. \& Watson-Will, A. (1998). Writing speed and legibility of 7-14-year-old school students using modern cursive script. Australian Occupational Therapy Journal, 45. 


\section{Extended Abstract}

\section{Introduction}

People use different ways to communicate with other people around them. One of the most frequently preferred ways of communication is writing. They transfer what they know by writing skills and express themselves. Elementary school years when learning to read and write are the basis of writing skills. The general aim of the first literacy education is to gain necessary skill set that will be used throughout life, based on visual reading, listening, speaking and visual presentation skills which all have been acquired spontaneously with its experiences until the school. One of the goals of the first grade teacher in the process of teaching how to read and write should be to gain the knowledge and skills of aesthetic, legible and good writing which is fast, fluent, in accordance with the rules and requirements of the age, and critical (Yılar, 2015). In the process after the first literacy is learned, students are expected to have the ability to write at a certain speed. It is also expected to produce legible, understandable written products. Students who cannot improve their writing skills in the elementary education, which is the basis of education, may encounter problems such as low writing speed in the following years and being unable to use the time effectively in exams, failing to transfer what they know in writing or failing to express themselves in writing. Therefore, these students do not like to write in the following years and refrain from producing written products. This study aims to investigate the legibility and writing speed of elementary school first grade students by rewriting, writing, hearing (dictation) and free writing skills, since gaining writing skills is very important and the foundation of writing skill is formed in elementary school years. In accordance with this goal in the research, the research was intended to answer the following questions;

1. How legible is the writing (dictation), rewriting and free writing of elementary school first grade students?

2. What is the speed of writing (dictation), rewriting and free writing of elementary school first grade students?

3. What is the content of the free writings of elementary school first year students?

\section{Method}

In this research, descriptive survey model was applied. Survey researches that are frequently used in social sciences are the studies conducted on large groups, where the individuals in the group have their opinions, attitudes about a case and event, and cases and events are tried to be described (Karakaya, 2011, p.59). The survey model provides the opportunity to investigate and describe an existing event or a past event. In this model, the researcher is not intended to influence or change the event. It aims to describe the current situation as it is. The data required for the research were obtained from 25 first year students studying at a public school in Gölhisar district of Burdur province at the end of the first semester (December) of 2019-2020 academic year. 13 girls and 12 boys participated in the research. In the research, three-spaced guideline worksheet was used as data collection tool. "Dictation Study Follow-Up Form" developed by Akyol and Yıldız (2018) was used for dictation work, writing by looking and free writing. Upon having taken the field expert opinion about the form, 2 items were removed, and one item was added. The form consisted of 10 items in total. The " Holistic Rubric for Writing a Story for Elementary School" developed by Akyol and Yıldız (2018) for free writing was adapted to the first grades. During this process, the opinions of two first grade teachers (20 years and 14 years of professional experience) were taken. Students were given 20 minutes for free writing. Regarding the texts, two class teachers and a field expert of first literacy were consulted and the texts were edited in line with their feedback. Legibility and free writing content analysis were examined by three different raters, and reliability analysis was administered. Two class teachers ( 20 years and 14 years of professional experience) and the researcher were decided as scorekeepers. Worksheet about dictation, rewriting, writing and free writing were collected from students and were coded as Ö1, Ö2.

\section{Result and Discussion}

According to the results of this research, the writing speed of the students in free writing was generally lower than the writing speed in dictation and rewriting speed. In addition, according to the 
research findings, students made spelling errors such as missing out letters and adding extra letters. The aim of this study is to determine the readability and writing speed of first grade students with vertical basic letters. If a student does not learn to write correctly, $\mathrm{s} /$ he may find it difficult to produce something, as $s /$ he focuses on the rules of writing. Likewise, if a student cannot improve his/her writing speed at the speed appropriate for the level, s/he may not enjoy writing. These situations may affect academic success, negatively. Therefore, teachers should focus on legibility studies and free writing activities in writing instruction. In addition, it can be investigated whether the writing speed differs according to different text types. Further research can be conducted to examine the change in the legibility of writing and the speed of writing of the same working group. How both the legibility and writing speed differ in preschool education can also be examined. 